\title{
The Pluri-Extractivist State: Regional Autonomy and the Limits of Indigenous Representation in Bolivia's Gran Chaco Province
}

\author{
Penelope Anthias* \\ Assistant Professor, Department of Geography, Durham University \\ ${ }^{*}$ Corresponding author. Email: penelope.f.anthias@durham.ac.uk
}

(Received 18 September 2019; revised 16 August 2021; accepted 25 August 2021;

first published online 17 January 2022)

\begin{abstract}
On 20 November 2016, residents of Gran Chaco Province in south-east Bolivia voted by popular referendum to approve a statute that established Gran Chaco as Bolivia's first autonomous region. This article examines regional autonomy in the Chaco as an example of how identities, territory and political power are being remapped at the intersection of an extractivist development model and competing visions of a plurinational state. I chart how regional autonomy, an elite-led project centred on demands for a fixed share of departmental gas royalties, has been institutionalised under the framework of plurinationalism and used to bolster central state power in this gas-rich region. The article considers the historical evolution of this regionalist project, its intersection with broader processes of state formation under the Movimiento al Socialismo (Movement towards Socialism, MAS) government and its implications for the Chaco's Indigenous peoples, who have achieved significant representation within the regional assembly while seeing their own visions of territorial autonomy sidelined by an extractivist development agenda.
\end{abstract}

Keywords: Bolivia; extractivism; plurinationalism; autonomy; state formation; Indigenous peoples

In this land blessed by hydrocarbons, through the present Regional Autonomy Statute we will form a self-government that allows us [...] to make Gran Chaco the main centre of development in Bolivia, an articulating centre of Bolivianness and geographical reference point of the South American Chaco. The tenacious struggle of the original chaqueños to shake off all dependency flowed in the people that bravely fought for 45 per cent of the hydrocarbon royalties; subsequently demanded autonomy and conquered it democratically through the vote, as the corollary of its historically autonomous vocation. Here is the First Autonomous Statute of the Gran Chaco Region that expresses the feeling and the aspirations of the Chaco people. LONG LIVE GRAN CHACO!

(C) The Author(s), 2022. Published by Cambridge University Press. This is an Open Access article, distributed under the terms of the Creative Commons Attribution licence (https://creativecommons.org/licenses/by/4.0/), which permits unrestricted re-use, distribution, and reproduction in any medium, provided the original work is properly cited. 
- Excerpt from preamble, Regional Autonomy Statute of the Gran Chaco,

September $2016^{1}$

\section{Introduction}

On 20 November 2016, residents of Gran Chaco Province ${ }^{2}$ in Tarija Department in south-east Bolivia voted by popular referendum to approve a statute that established Gran Chaco as Bolivia's first 'autonomous region' - one of several levels of autonomy recognised in Bolivia's 2009 Constitution. ${ }^{3}$ Underpinning Gran Chaco's successful autonomy bid was a claim to receive and administer 45 per cent of the hydrocarbon royalties allocated to Tarija Department, which contains most of Bolivia's gas reserves. ${ }^{4}$ These resources constitute the main source of national income in Bolivia and the economic basis for the 'process of change' implemented by President Evo Morales from 2006. The recognition of Gran Chaco as an autonomous region makes this remote, semi-arid and sparsely populated province, in fiscal terms at least, the richest in Bolivia.

Gran Chaco's regional autonomy project is illustrative of how identity, territory and political power are being remapped in the context of Bolivia's recent hydrocarbon boom and neo-extractivist development model, in ways that are producing new territorialities. What is perhaps most striking, however, is that this elite-led extractivist project is being advanced and legitimised through the constitutional framework of Bolivia's plurinational state. This article considers the historical evolution of resource regionalism in the Chaco, its intersection with broader processes of state formation under the Movimiento al Socialismo (Movement towards Socialism, MAS) government (2005-19; 2020-present) and its implications for Indigenous decolonial struggles.

As I will go on to describe, demands for regional autonomy reflect long-standing 'resource grievances' related to the Chaco's status as a gas-producing region and its marginality within departmental and national politics. ${ }^{5}$ This project gained a new lease of life under the MAS government, which saw regional autonomy as a means of weakening the power of Tarija's right-wing departmental elite and consolidating its own power over the Chaco and its gas fields. Gran Chaco's regional autonomy thus demonstrates how Indigenous visions of a plurinational state are being

\footnotetext{
${ }^{1}$ All translations are my own, unless otherwise indicated. In some cases, pseudonyms have been used to protect the identities of individuals. The Regional Autonomy Statute of the Gran Chaco is available at www. argch.gob.bo/wp-content/uploads/2018/01/Estatuto-Auton\%C3\%B3mico-Regional-del-Gran-Chaco.pdf, last access 29 Nov. 2021.

${ }^{2}$ Gran Chaco Province comprises the eastern part of Tarija Department in the south of Bolivia, bordering Argentina to the south, Paraguay to the east, and the Bolivian department of Chuquisaca to the north. It forms part of the South American Chaco (sometimes also called Gran Chaco), an ecological region that also extends over parts of Santa Cruz and Chuquisaca departments in Bolivia, as well as western Paraguay, northern Argentina and the Brazilian states of Mato Grosso and Mato Grosso do Sul.

${ }^{3}$ Bolivia's 2009 Constitution, Articles 281-3, available at https://sea.gob.bo/digesto/Compendio Normativo/01.pdf, last access 29 Nov. 2021.

${ }^{4}$ This claim for 45 per cent was justified on the basis that Gran Chaco represents 45 per cent of Tarija Department's land area.

${ }^{5}$ See Denise Humphreys Bebbington and Anthony Bebbington, 'Anatomy of a Regional Conflict: Tarija and Resource Grievances in Morales's Bolivia', Latin American Perspectives, 37: 4 (2010), pp. 140-60.
} 
appropriated by, and subordinated to, the territorial dynamics of a neo-extractivist development agenda, providing a basis for new (but historically familiar) sovereign alignments between state resource interests and agrarian elites in the Chaco.

The article also considers the implications of regional autonomy for the Chaco's Indigenous peoples - the Guaraní, Weenhayek and Tapiete - whose ancestral territories contain the region's most important gas reserves. While regional autonomy began as an elite-led project that excluded them, these Indigenous peoples have now achieved significant representation within Gran Chaco's regional assembly. However, I argue that racialised inequalities, clientelist relations and bureaucratic constraints limit what Indigenous representatives are able to achieve within such political spaces. Meanwhile, Indigenous territorial claims continue to be obstructed by regional elites and the MAS government, and the direct impacts of extraction in these territories continue to accumulate. Notwithstanding these limits, the testimonies of Indigenous representatives make clear that they are not simply political instruments of regional and national elites, but are slowly and patiently seeking to carve out spaces within the pluri-extractivist state to pursue their own claims to postcolonial recognition and resource justice.

The article is structured as follows. The first section sets out a theoretical framework for understanding the Chaco's regional autonomy project at the intersection of extractivism and plurinationalism. The second section describes the historical emergence and evolution of Gran Chaco's regional autonomy project from the 1930s to the present. The final section explores the shifting position of Chaco Indigenous peoples within this regional autonomy project, the constraints faced by elected Indigenous representatives and how they reflect on their positions in relation to broader Indigenous agendas for decolonising the state.

Research for this article involved institutional ethnography, documentary analysis and interviews conducted during three two-month trips in 2016, 2017 and 2019. This included several periods of participant observation within the Autonomous Regional Assembly of Gran Chaco, where I discussed regional autonomy and day-to-day politics with Indigenous representatives, non-Indigenous politicians and technical staff, and observed political meetings, administrative processes and civic events. In 2017, I conducted interviews with chaqueño political leaders and Indigenous representatives within the Chaco's regional assembly and Tarija's departmental legislative assembly. The article also draws on my broader engagements with Indigenous movements in the Chaco since 2008, which have focused primarily on their struggles for territory. Throughout the article, pseudonyms are used to protect the identities of research participants.

\section{Territory, Extractivism and Plurinationalism}

The recent extractive industry boom in Latin America and the rise (and in some cases fall) of leftist governments has generated a vast literature exploring the shifting dynamics of extractivism in the region, including its implications for citizenship, the environment and Indigenous peoples. ${ }^{6}$ Much of this literature has focused on how extractive industry projects threaten and are resisted by local

\footnotetext{
${ }^{6}$ Extractivism denotes a 'pattern of accumulation based on the overexploitation of generally nonrenewable natural resources, as well as the expansion of capital's frontiers toward territories previously
} 
groups, producing socio-environmental conflicts. In this regard, the territorial dynamics of 'neo-extractivist' or 'progressive extractivist' regimes have much in common with those of their neoliberal counterparts. ${ }^{7}$ Bolivia and Ecuador have been seen as emblematic of the contradictions between leftist states' discourse on Indigenous rights and the environment and dependence on resource rents to finance social and infrastructure spending. ${ }^{8}$ Maristella Svampa argues that such conflicts are giving rise to a new 'eco-territorial turn', as Indigenous and environmentalist movements converge around forms of place-based resistance to extractivism. ${ }^{9}$

Yet the territorial dynamics of extractivism are not limited to environmental dispossession and the local defence of territory. Diverse local actors also seek to shape how extraction happens and who benefits from it. ${ }^{10}$ Where efforts to prevent extraction from happening fail (as they often do), issues of environmental governance, access to employment, compensation and the distribution of resource rents often emerge as the enduring focus of political contestation. Of course, hydrocarbon companies actively seek to channel local agency into demands for recognition and benefit-sharing. ${ }^{11}$ Such local engagements with extraction produce new forms of territoriality, which may challenge, as well as articulate with, resource nationalist projects. ${ }^{12}$ Felipe Irarrázaval describes the emergence of 'metano-territorialities', as

considered nonproductive'. See Maristella Svampa, 'Commodities Consensus: Neoextractivism and Enclosure of the Commons in Latin America', South Atlantic Quarterly, 114: 1 (2015), p. 66.

${ }^{7}$ See ibid.; Eduardo Gudynas, 'Diez tesis urgentes sobre el nuevo extractivismo', in Jürgen Schuldt, Alberto Acosta, Alberto Barandiarán, Mauricio Folchi, CEDLA - Bolivia, Anthony Bebbington, Alejandra Alayza and Eduardo Gudynas (eds.), Extractivismo, política y sociedad (Quito: CAAP; CLAES, 2009), pp. 187-225; Alberto Acosta, 'Extractivism and Neo-Extractivism: Two Sides of the Same Curse', in Miriam Lang and Dunia Mokrani (eds.), Beyond Development: Alternative Visions from Latin America. Quito and Amsterdam (Quito: Transnational Institute/Rosa Luxemburg Foundation, 2013), pp. 61-86; Anthony Bebbington and Denise Humphreys Bebbington, 'An Andean Avatar: Post-Neoliberal and Neoliberal Strategies for Securing the Unobtainable', New Political Economy, 16: 1 (2011), pp. 131-45.

${ }^{8}$ See Arturo Escobar, 'Latin America at a Crossroads: Alternative Modernizations, Post-Liberalism, or Post-Development?', Cultural Studies, 24: 1 (2010), pp. 1-65; Jessica Hope, 'Losing Ground? Extractive-Led Development versus Environmentalism in the Isiboro Secure Indigenous Territory and National Park (TIPNIS), Bolivia', Extractive Industries and Society, 3: 4 (2016), pp. 922-9; Diego Andreucci and Isabella M. Radhuber, 'Limits to "Counter-Neoliberal" Reform: Mining Expansion and the Marginalisation of Post-Extractivist Forces in Evo Morales's Bolivia', Geoforum, 84 (Aug. 2017), pp. 280-91.

${ }^{9}$ Svampa, 'Commodities Consensus', p. 66. See also Pabel López and Milson Betancourt (eds.), Conflictos territoriales y territorialidades en disputa: Re-existencias y horizontes societales frente al capital en América Latina (Buenos Aires: CLACSO, 2021).

${ }^{10}$ See John-Andrew McNeish, 'Extraction, Protest and Indigeneity in Bolivia: The TIPNIS Effect', Latin American and Caribbean Ethnic Studies, 8: 2 (2013), pp. 221-42; Denise Humphrey Bebbington and Anthony Bebbington, 'Extraction, Territory, and Inequalities: Gas in the Bolivian Chaco', Canadian Journal of Development Studies/Revue canadienne d'études du développement, 30: 1-2 (2011), pp. 25980; Francisco Javier Arellano-Yanguas and Andrés Mejia Acosta, 'Extractive Industries, Revenue Allocation and Local Politics', UNRISD Working Paper, No. 2014-4 (Geneva: UNRISD, 2014).

${ }^{11} J u d i t h$ Verweijen and Alexander Dunlap, 'The Evolving Techniques of the Social Engineering of Extraction: Introducing Political (Re)actions "From Above" in Large-Scale Mining and Energy Projects', Political Geography, 88 (June 2021), pp. 1-8.

${ }^{12}$ Michael Watts, 'Resource Curse? Governmentality, Oil and Power in the Niger Delta, Nigeria', Geopolitics, 9: 1 (2004), pp. 50-80. 
different social groups develop spatial practices that seek to develop to 'modify, refuse or access benefits from the natural gas production network'. ${ }^{3}$

In Bolivia, nationalist articulations of nature and nation under the MAS government have been accompanied by 'competing modes of spatial practice' as local actors seek to reconfigure the relationship between citizenship and the subsoil 'from the ground up' - from right-wing departmental autonomy movements, to mining cooperatives seeking direct agreements with transnational companies, to gas-fuelled visions of Indigenous autonomy. ${ }^{14}$ The Chaco region of Tarija, which contains most of Bolivia's gas reserves, has been a key site for subnational territorial projects linked to the governance of gas. ${ }^{15}$

A focus on such extractivisms 'from below' challenges state-centric analyses of leftist governments, revealing how political authority and state formation are not pre-given or static, but are constituted through local conflicts over land and resources. ${ }^{16}$ As Michael Watts argues in the Nigerian context, 'access to resource rents amplifies [...] subnational institution-making; politics becomes then a massive state-making machine'. ${ }^{17}$ While proponents of resource-curse theory have long observed such dynamics, recent work by geographers and anthropologists looks beyond economic competition to situate such conflicts within longer postcolonial struggles over territory, citizenship and nation. ${ }^{18}$ This work provides an important starting point for understanding Gran Chaco's regional autonomy project.

\footnotetext{
${ }^{13}$ Felipe Irarrázaval, 'Metano-territorialidades: La “era del gas natural” en Perú y Bolivia', Journal of Latin American Geography, 17: 3 (2018), p. 153.

${ }^{14}$ On hydrocarbon nationalism, see Thomas Perreault and Gabriela Valdivia, 'Hydrocarbons, Popular Protest, and National Imaginaries: Ecuador and Bolivia in Comparative Context', Geoforum, 41: 5 (2010), pp. 689-99; on 'competing modes of spatial practice', see Bret Gustafson, 'Flashpoints of Sovereignty: Natural Gas and Spatial Politics in Eastern Bolivia', in Andrea Behrends, Stephen P. Reyna and Günther Schlee (eds.), Crude Domination: An Anthropology of Oil (New York and Oxford: Berghahn, 2011), pp. 220-42; on departmental autonomy movements, see Benjamin Kohl and Rosalind Bresnahan, 'Introduction: Bolivia under Morales: Consolidating Power, Initiating Decolonization', Latin American Perspectives, 37: 3 (2010), pp. 5-17; on mining cooperatives, see Andrea Marston and Amy Kennemore, 'Extraction, Revolution, Plurinationalism: Rethinking Extractivism from Bolivia', Latin American Perspectives, 46: 2 (2019), pp. 141-60; on gas-funded Indigenous autonomy, see Penelope Anthias, Limits to Decolonization: Indigeneity, Territory and Hydrocarbon Politics in the Bolivian Chaco (Ithaca, NY, and London: Cornell University Press, 2018).

${ }^{15}$ Humphreys Bebbington and Bebbington, 'Anatomy of a Regional Conflict'; 'Extraction, Territory, and Inequalities: Gas in the Bolivian Chaco'; Leonith Hinojosa, Anthony Bebbington, Guido Cortez, Juan Pablo Chumacero, Denise Humphreys Bebbington and Karl Hennermann, 'Gas and Development: Rural Territorial Dynamics in Tarija, Bolivia', World Development, 73 (Sept. 2015), pp. 105-17; Pilar Lizárraga, Carlos Vacaflores and Juan Carlos Arostegui, 'Dinámicas de reconfiguración política en el departamento de Tarija' (2010), available at www.academia.edu/8082917/Dinámicas_de_reconfiguración_ política_bn_el_departamento_de_Tarija._Pilar_Lizárraga_Carlos_Vacaflores_Juan_Carlos_Arostegui, last access 2 Nov. 2021.

${ }^{16}$ Christian Lund, 'Rule and Rupture: State Formation through the Production of Property and Citizenship', Development and Change, 47: 6 (2016), pp. 1199-228.

${ }^{17}$ Michael Watts, 'Resource Curse?', p. 72.

${ }^{18}$ Ibid., pp. 50-80; Perreault and Valdivia, 'Hydrocarbons, Popular Protest, and National Imaginaries'; Anthias, Limits to Decolonization; Bret Gustafson, Bolivia in the Age of Gas (Durham, NC, and London: Duke University Press, 2020).
} 
Yet my interest, in this article, is not merely in how local state-making occurs in neo-extractivist states, but in the implications for decolonising the state and territory. It is here that the concept of plurinationalism is relevant, as a key point of articulation between Indigenous decolonial projects and local state formation in Bolivia. Plurinationalism has been understood by Bolivian intellectuals as a response to the crisis of a unitary state inherited from the colonial and republican periods, which failed to reflect the plurality or 'motley' (abigarrado) nature of the Bolivian population. ${ }^{19}$ Concretely, the vision of a plurinational state in Bolivia emerged from Indigenous movements and their long-standing claims to selfgovernance of their ancestral territories. ${ }^{20}$ It was developed by the Plurinational Constituent Assembly of 2006-8, where representatives of Indigenous and peasant organisations participated in rewriting Bolivia's national Constitution. ${ }^{21}$ The 2009 Constitution redefines Bolivia as a 'plurinational state' and recognises Indigenous peoples' right to self-governance through the constitution of autonomías indígenas originarias campesinas (Indigenous peasant autonomies, AIOCs), among other measures. ${ }^{22}$ The Constitution identifies three routes to Indigenous autonomy: (i) the conversion of already-existing municipalities; (ii) the conversion of tierras comunitarias de origen (Indigenous community lands, TCOs), renamed territorios indígena originario campesinos (Indigenous peasant territories, TIOCs); and (iii) the creation of regional Indigenous autonomies composed of two or more converted municipalities.

As other scholars have noted, the 2009 Constitution represents a 'domestication' of Indigenous peoples' vision of autonomy. ${ }^{23}$ Moreover, the implementation of Indigenous autonomy in practice has stalled due to a combination of procedural obstacles and the MAS government's economic dependence on resource extraction in Indigenous territories. ${ }^{24}$ As such, previous scholarship has tended to treat

\footnotetext{
${ }^{19}$ Raúl Prada, 'Análisis de la nueva Constitución Política del Estado', in Crítica y emancipación: Revista latinoamericana de Ciencias Sociales, 1: 1 (2008), pp. 35-50, available at http://biblioteca.clacso.edu.ar/gsdl/ collect/clacso/index/assoc/D2052.dir/3S1b.pdf, last access 2 Nov. 2021; 'Articulaciones de la complejidad: Estado plurinacional', Bolpress, 2 March 2007, available at www.bolpress.com/art.php?Cod=2007022803, last access 2 Nov. 2021; Luís Tapia Mealla, La condición multisocietal: Multiculturalidad, pluralismo, modernidad (La Paz: CIDES-UMSA/Muela del Diablo Editores, 2002); Roger Merino, 'Reimagining the Nation-State: Indigenous Peoples and the Making of Plurinationalism in Latin America', Leiden Journal of International Law, 31: 4 (2018), pp. 773-92.

${ }^{20}$ While Indigenous territorial demands were recognised in agrarian law as tierras comunitarias de origen (Indigenous community lands, TCOs) in 1996, aspirations for autonomous governance of these territories remained unfulfilled during the neoliberal period. See Anthias, Limits to Decolonization.

${ }^{21}$ Salvador Schavelzon, El nacimiento del Estado Plurinacional de Bolivia: Etnografía de una Asamblea Constituyente (La Paz: CLACSO-PLURAL-IWGIA-CEJIS, 2002).

${ }^{22}$ In addition to provisions for Indigenous autonomy, the 2009 Constitution deepens intercultural policies in education and health, stipulates designated seats in Congress and the Supreme Court for Indigenous representatives, and establishes new language requirements for state employees. See Merino, 'Reimagining the Nation-State'.

${ }^{23}$ Fernando Garcés, 'The Domestication of Indigenous Autonomies in Bolivia: From the Pact of Unity to the New Constitution', in Bret Gustafson and Nicole Fabricant (eds.), Remapping Bolivia: Resources, Territory, and Indigeneity in a Plurinational State (Santa Fe, NM: SAR Press, 2011), pp. 46-67.

${ }^{24}$ Specifically, most lowland Indigenous peoples are unable to achieve autonomy as TIOCs due to the unconsolidated and fragmented status of Indigenous land rights, and cannot achieve municipal autonomy due to their inability to win a municipal referendum. See Jason Tockman and John Cameron, 'Indigenous Autonomy and the Contradictions of Plurinationalism in Bolivia', Latin American Politics and Society, 56: 3
} 
extractivism and plurinationalism as contradictory forces within Bolivia's 'process of change'. Without contesting this contradiction between Indigenous autonomy and extractivism, this article argues that extractivism and plurinationalism are also becoming articulated in local processes of territory and state formation in the Bolivian Chaco, with significant consequences for Indigenous decolonial projects. Specifically, Gran Chaco's regional autonomy process shows how local dynamics of extractivist state formation are redefining the meaning and content of plurinationalism in the Chaco, in ways that marginalise alternative Indigenous visions of territory and autonomy. I use the term pluri-extractivism to describe and critique this articulation.

One the one hand, I chart how regional elites' resource claims have been reframed, legitimised and institutionalised within the framework of Bolivia's plurinational state - the 2009 Constitution and the 2010 Ley Marco de Autonomías y Descentralización (Autonomy and Decentralisation Framework Law). I argue that the MAS government has supported this autonomy process as a means to consolidate its own power within the gas-rich Chaco in the face of departmental opposition in Tarija. Meanwhile, Indigenous peoples - the intellectual architects and intended beneficiaries of the plurinational state - continue to have their claims to territory effaced and obstructed, both by local agrarian elites and by an extractivist state.

Yet, plurinationalism and extractivism are also becoming articulated in a second way, which is of relevance to this article. Indigenous and peasant organisations have emerged as active participants in struggles over gas-rents distribution in Tarija, where political actors cannot avoid engaging in the politics of extraction. ${ }^{25}$ In this context, local control of gas rents is seen by diverse local actors as an essential part of building a plurinational state; as I was frequently told on recent trips to Tarija, 'sin recursos no hay autonomía [without resources there is no autonomy]'. While Indigenous demands for a direct share of national or departmental hydrocarbon rents have been frustrated by elite opposition and formal Indigenous autonomy remains inaccessible, some Indigenous leaders see occupying positions within local state institutions as a means of directing hydrocarbon rents towards rural Indigenous communities, who suffer from chronic underinvestment alongside the direct socio-ecological impacts of extraction.

The construction of regional autonomy in Gran Chaco sits at the intersection of these two processes. On the one hand, chaqueño elites have sought to include Indigenous peoples in their regionalist project as a means to gain political legitimacy and increase their capacity for social mobilisation (such as road blockades) in the face of strong opposition from departmental elites. On the other hand, Indigenous organisations have actively fought for inclusion in regional autonomy as a means to advance their own political agendas - inclusion within regional

(2014), pp. 46-69; Nancy Postero, The Indigenous State: Race, Politics, and Performance in Plurinational Bolivia (Oakland, CA: University of California Press, 2017). It is worth noting that Chaco Indigenous peoples also attribute the partial implementation of Indigenous land rights to state interests in resource extraction in their territories; see Anthias, Limits to Decolonization.

${ }^{25}$ This takes various forms, including compensation agreements with oil companies, demands for a fixed share of departmental hydrocarbon royalties, a contested national Indigenous Fund, and lobbying state institutions to direct resources to rural communities. See Hinojosa et al., 'Gas and Development'. 
planning processes, the allocation of state funds to Indigenous development priorities, and the breaking down of historic structures of racialised rule that frame Indigenous peoples as incapable of holding political office or managing resources. It is important to note that Gran Chaco's regional autonomy is just one expression of how plurinationalism and extractivism are being articulated, with its own particular set of dynamics. Further research is required to examine other iterations of pluri-extractivism in Bolivia - and indeed, whether the term has any broader resonance beyond the Chaco. I now turn to the origins of regional autonomy in the Chaco, which underline the historical and geographical specificity of this project.

\section{The Origins of Regional Autonomy in the Bolivian Chaco}

\section{A Neglected Hydrocarbon Frontier}

Stretching from the sub-Andean mountain range of Aguaragüe in the west to the arid Chaco plains in the east, the Chaco region of Tarija Department has historically been at the political and imaginative margins of the Bolivian nation-state. While non-Indigenous settlement in the region began in the late eighteenth century, strong military resistance by the Guaraní meant that Bolivian state forces did not have military control of the region until the late nineteenth century. ${ }^{26}$ The first paved road connecting the Chaco to the Bolivian altiplano (highlands) and the capital La Paz was not built until the 1930s. This historic isolation has contributed towards a strong regional identity, with most residents of the Chaco identifying themselves as chaqueños rather than as tarijeños.

The 1932-5 Chaco War with Paraguay marked a turning point in the region's history. The war brought thousands of largely poor Aymara- or Quechua-speaking peasants from the Andes to fight in defence of the Chaco's oil and gas reserves, where many of them perished due to extreme heat, lack of training and equipment and poor military leadership. ${ }^{27}$ Although Paraguay won the war and was awarded three-quarters of the disputed Chaco Boreal, the portion that remained in Bolivia contained some of South America's most important oil and gas reserves. The end of the war saw an intensification of hydrocarbon development, following the creation of the Bolivian state-owned oil company Yacimientos Petrolíferos Fiscales Bolivianos (YPFB) in 1936 and nationalisation of hydrocarbons reserves in 1937. This period also brought many new settlers to the region, as the Bolivian state encouraged ex-combatants to occupy the Chaco's gas-rich lands, a process that exacerbated Indigenous dispossession and the spread of forced-labour practices. ${ }^{28}$

\footnotetext{
${ }^{26}$ See Erick D. Langer, Expecting Pears from an Elm Tree: Franciscan Missions on the Chiriguano Frontier in the Heart of South America, 1830-1949, 2nd ed. (Durham, NC: Duke University Press, 2009).

${ }^{27}$ Bolivia lost between 56,000 and 65,000 , comprising 2 per cent of its population, while Paraguay lost about 36,000, or 3 per cent of its population; see Matthew Hughes, 'Logistics and the Chaco War: Bolivia versus Paraguay, 1932-1935', Journal of Military History, 69: 2 (2005), pp. 411-37. While the Chaco War is widely presented in Bolivia as a proxy war between Standard Oil and Royal Dutch Shell, historians have argued that it reflected internal political rivalries among Bolivian elites; see Herbert S. Klein, Bolivia: The Evolution of a Multi-Ethnic Society (New York and Oxford: Oxford University Press, 1992).

${ }^{28}$ Anthias, Limits to Decolonization.
} 
The Chaco's emergence as a hydrocarbon frontier, combined with its marginality to national and departmental development, created the conditions for the first iteration of a regional autonomy movement. Following the Chaco War, the 1941 Royalties Law allocated an 11 per cent royalty to hydrocarbon-producing departments. ${ }^{29}$ In Tarija Department, this money was managed by departmental elites based in the temperate colonial city of Tarija at some distance from the arid Chaco and its gas fields (see Figure 1). Few of these resources were channelled into Gran Chaco Province, which continued to lack basic infrastructure. In 1983, following Bolivia's return to democratic rule, politicians from Gran Chaco began meeting with political leaders in the Chaco region of neighbouring Santa Cruz and Chuquisaca departments. ${ }^{30}$ The result was a joint proposal for the creation of a 'tenth department' in the Bolivian Chaco. Known as the Pacto de Quebracho, this agreement was based on shared grievances regarding the centralism of national and departmental governments and an agro-industrial vision of regional economic development.

A 1989 newspaper article entitled 'The Chaco ... German Busch Department?' (see Figure 2) is illustrative. Detailing the sacrifices of the disastrous Chaco War, the authors lament:

After the traumatic military contest, the country didn't know any more of the Chaco and its people. On looking there, governments only saw oil deposits and towers. They never understood what the Chaco is ... [the Chaco's] historic unity has always been submerged in backwardness and dependency, so its future always had to await solutions in three capitals of different departments (Santa Cruz, Sucre and Tarija), that could never fulfil the hopes of this people. $^{31}$

The authors go on to make a case for regional autonomy, asking: 'Why not a Department of the Chaco? What mean interests could prevent [...] us from overcoming this arbitrariness of our history through which this vigorous region was severed, fragmented and condemned to live in three different and faraway Departments? ${ }^{32}$ As Figure 2 makes clear, Chaco Indigenous peoples were not considered within this vision of regional development - other than perhaps as an element of the Chaco's historic 'backwardness'.

While this tenth department never materialised, the threat it posed to Tarija's departmental elites played an important role in ongoing negotiations over the interdepartmental distribution of gas rents. In parallel with the Pacto de Quebracho, leaders in Gran Chaco Province put forward a demand to receive 45 per cent of the 11 per cent of gas royalties received by Tarija Department, based on the argument that Gran Chaco represents 45 per cent of Tarija Department's territory.

\footnotetext{
${ }^{29}$ Humphreys Bebbington and Bebbington, 'Anatomy of a Regional Conflict'.

${ }^{30}$ Lizárraga et al., 'Dinámicas de reconfiguración política en el Departamento de Tarija'.

${ }^{31}$ Ramiro Antelo León and Oscar G. Montes, 'El Chaco ... Departamento German Busch', photocopy of newspaper article, dated August 1989, located in an archive of the NGO Centro de Estudios Regionales de Tarija (Centre for Regional Studies of Tarija, CERDET), title of newspaper unknown.

${ }^{32}$ Ibid.
} 


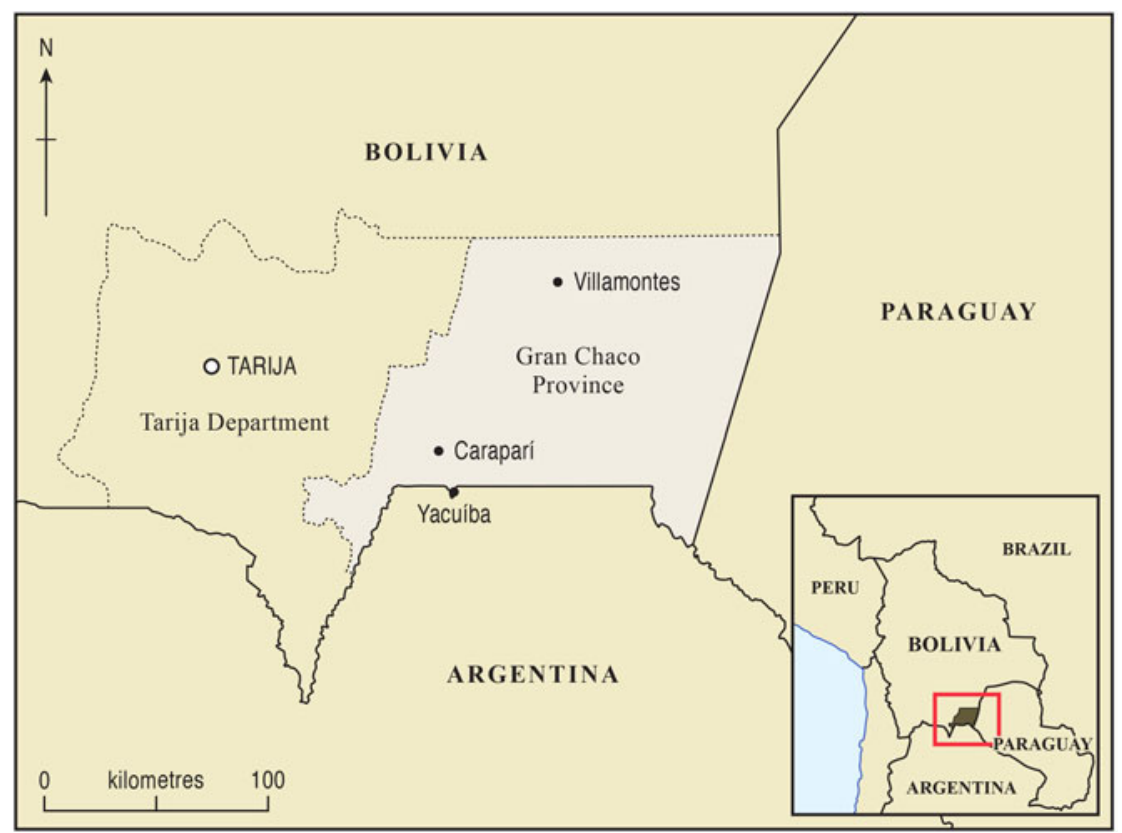

Figure 1. Map Showing Location of Gran Chaco Province in Tarija Department, Bolivia Source: Map compiled by Chris Orton in the Cartographic Unit, Department of Geography, Durham University.

Tarija's departmental government responded by passing Resolution 16/83, which established that 45 per cent of annual hydrocarbon royalties generated by Gran Chaco Province should be invested in the province. However, there were repeated delays in transferring these resources and most of the money went to Yacuiba, the seat of the sub-prefecture and the most populous of Gran Chaco's three municipalities. This was exacerbated by the 1994 Ley de Participación Popular (Popular Participation Law), which allocated state funds to municipalities based on population. As local politician Fermin Ramos explained: 'First there was a draining centralisation in the department and later there was a centralisation in Yacuiba as the capital of the province [...] from there the spirit of being autonomous was born - to be able to manage our own resources, to be able to elect our own authorities and to be able to plan our own development. ${ }^{33}$

As this brief overview makes clear, Gran Chaco's regional autonomy project has its origins in long-standing 'resource grievances' regarding the Chaco region's emergence as a hydrocarbon frontier and its marginality to national and departmental development. ${ }^{34}$ Nevertheless, the realisation of this project has been made possible by a set of more recent political transformations: first, the gas boom of the 1990s and resulting struggles over the governance of the subsoil that marked Morales' rise to power; and second, the institutionalisation of Indigenous visions

\footnotetext{
${ }^{33}$ Author interview with Fermin Ramos, local politician, Regional Assembly of Gran Chaco Province in Karaparí, Tarija Department, 11 April 2017.

${ }^{34}$ See Humphreys Bebbington and Bebbington, 'Anatomy of a Regional Conflict'.
} 


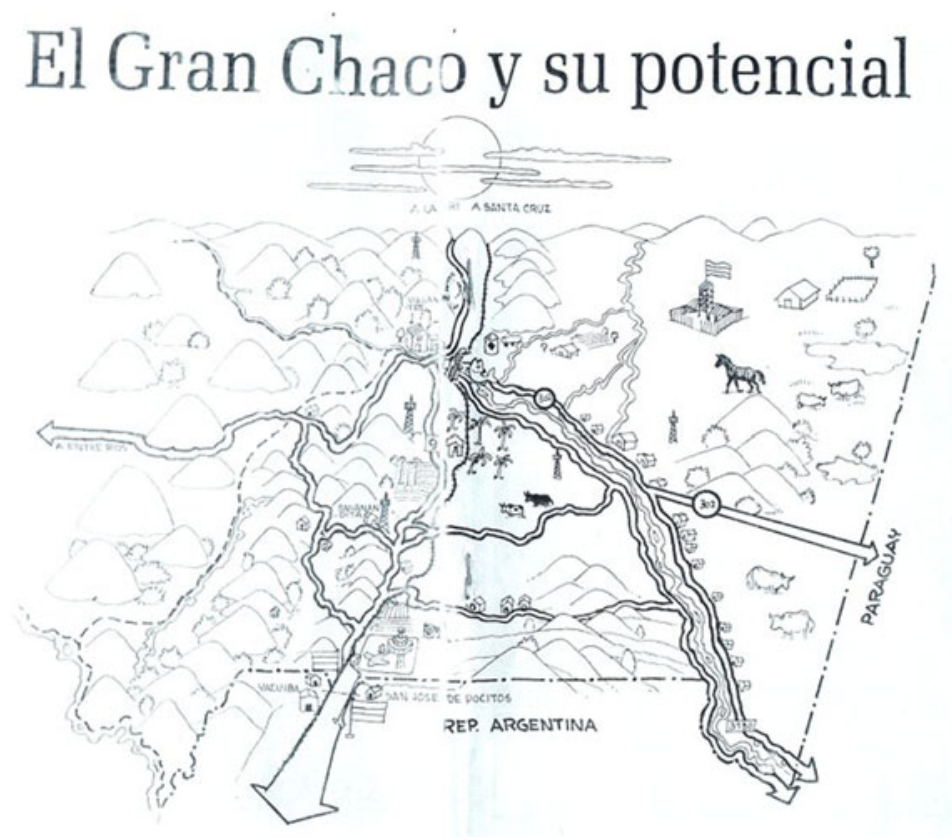

Figure 2. 'Gran Chaco and Its Potential'

Note: Illustration from 1989, which depicts the province as a site of hydrocarbon development, agro-industry and cattle ranching with commercial links to Argentina and Paraguay. No reference is made to the region's Indigenous peoples.

Source: Ramiro Antelo León and Oscar G. Montes, 'El Chaco ... Departamento German Busch?' (1989, found in archive of Centro de Estudios Regionales de Tarija).

of a plurinational state under the 2009 Constitution and 2010 Autonomy and Decentralisation Framework Law.

\section{A Neo-Extractivist Alliance}

As has been widely discussed, Bolivia's MAS government emerged from popular responses to neoliberalism and, more specifically, demands for the renationalisation of Bolivia's hydrocarbon reserves - a story in which the Chaco of Tarija (which contains approximately 85 per cent of these reserves) played a central role. ${ }^{35}$ In 2003, plans to allow export of liquefied natural gas (LNG) from the Chaco to the United States via Chile, Bolivia's historic rival, sparked national protests and demands for a renationalisation of Bolivia's gas fields. Following the deaths of 80 people in clashes with the police in the 2003 Gas War, President Sánchez de Lozada was forced to resign, paving the way for the election of Morales two years later. On assuming office in January 2005, Morales passed the 'Heroes of the Chaco' Decree nationalising hydrocarbons. The Chaco's gas fields were

\footnotetext{
${ }^{35}$ See Derrick Hindery, From Enron to Evo: Pipeline Politics, Global Environmentalism, and Indigenous Rights in Bolivia (Tucson, AZ: University of Arizona Press, 2013); Benjamin Kohl and Linda C. Farthing, Impasse in Bolivia: Neoliberal Hegemony and Popular Resistance (London: Zed, 2006).
} 
theatrically occupied by the military while contracts with transnational oil companies were renegotiated. ${ }^{36}$

These national struggles over the governance of the subsoil were accompanied by an escalation of political conflict in Gran Chaco Province relating to the transfer and distribution of hydrocarbon royalties by Tarija's departmental government. In 2001, a 14-day road blockade in the Chaco led Tarija's departmental council to pass a new resolution determining that Gran Chaco's 45 per cent would be distributed equally between its three municipalities. ${ }^{37}$ Ongoing delays with the transfer of funds led to further roadblocks in 2002. On 14 February 2004, Chaco leaders from Tarija, Santa Cruz and Chuquisaca departments formally renewed their pact to promote the creation of a tenth department. These struggles occurred in the context of an explosion of hydrocarbon development in the Chaco and a dramatic increase in royalties and Direct Hydrocarbon Tax flowing into the accounts of the departmental prefecture of Tarija. ${ }^{38}$

The national political crisis of $2003-5$ provided a context for a strategic alignment between these resource-nationalist and resource-regionalist projects. After being forced out by social protest in 2003, President Sánchez de Lozada was succeeded by his former vice-president Carlos Mesa. Mesa's multi-party interim government (2003-5) saw ongoing social protest from labour unions, right-wing autonomist movements, and the growing MAS party led by Morales. Amidst this social upheaval, Mesa made a pact with the leading chaqueño politician Wilman Cardozo, who agreed to support Mesa's government in exchange for Mesa's support for the Chaco's autonomy claim. ${ }^{39}$

This pact was renewed by Morales, who was elected president in 2005 after Mesa was forced from office. Morales' first term in office was rocked by coordinated autonomy campaigns by lowland departmental elites (2006-8), who viewed the new government as a threat to the established racial-spatial order and (in Tarija and Santa Cruz) to their own aspirations for control of the Chaco's gas wealth. ${ }^{40}$ In this context, Morales viewed Gran Chaco's regional autonomy project as a

\footnotetext{
${ }^{36}$ Perreault and Valdivia, 'Hydrocarbons, Popular Protest, and National Imaginaries'.

${ }^{37}$ Lizárraga et al., 'Dinámicas de reconfiguración política en el departamento de Tarija'.

${ }^{38}$ Departmental hydrocarbon revenues soared from approximately 534 million bolivianos in 2004 to over 1.67 million bolivianos in 2007, accounting for 89 per cent of the department's income; see Humphreys Bebbington and Bebbington, 'Anatomy of a Regional Conflict'. For analysis of hydrocarbon revenues over time, see Maria L. Aresti, 'Revenue Sharing Case Study: Oil and Gas Revenue Sharing in Bolivia' (National Resource Governance Institute, April 2016), available at https://resourcegovernance.org/analysis-tools/publications/revenue-sharing-case-study-oil-and-gas-revenue-sharing-bolivia, last access 8 Nov. 2021.

${ }^{39}$ Lizárraga et al., 'Dinámicas de reconfiguración política en el departamento de Tarija'.

${ }^{40}$ In a July 2006 referendum on departmental autonomy, Bolivia's four eastern lowland departments (Tarija, Santa Cruz, Beni, Pando) voted overwhelmingly in favour of establishing departmental autonomy, with more than 60 per cent in Tarija supporting it. In Dec. 2007, these lowland departments declared autonomy and pushed ahead with departmental referenda on autonomy (held in May-June 2008). See ibid.; Kohl and Bresnahan, 'Introduction: Bolivia under Morales'; Humphreys Bebbington and Bebbington, 'Anatomy of a Regional Conflict'; Mark Weisbrot and Luis Sandoval, 'The Distribution of Bolivia's Most Important Natural Resources and the Autonomy Conflicts', CEPR Reports and Issue Briefs, 22 (Center for Economic and Policy Research, 2008), available at www.cepr.net/report/the-distribution-of-bolivias-most-important-natural-resources-and-the-autonomy-conflicts/, last access 8 Nov. 2021.
} 
means to weaken Tarija's departmental autonomy campaign and strengthen central government control over Gran Chaco's gas fields, which provided the material foundation for his entire 'post-neoliberal' development project.

Contestation between a resource-nationalist government and right-wing campaigns for departmental autonomy thus provided a new opportunity for local non-Indigenous elites in Gran Chaco to pursue their historic claim for regional autonomy. While chaqueño leaders did support a 2006 referendum on departmental autonomy, they ultimately continued their alliance with the MAS government on the condition that it agreed to hold a binding referendum on regional autonomy in Gran Chaco Province. ${ }^{41}$ This referendum was held in conjunction with the referendum on Bolivia's new Constitution on 6 December 2009 and asked 'Are you in agreement that the province enters a regime of regional autonomy?' The 'yes' vote won, with a majority of 90 per cent. The victory was followed by the establishment of the Asamblea Regional del Gran Chaco (Regional Assembly of Gran Chaco Province), tasked with elaborating a regional autonomy statute.

Despite this victory, regional autonomy continued to be seen by many in the Chaco as a result of political manoeuvres by MAS and a few chaqueño politicians rather than a genuine grassroots demand. When I visited the region in 2011-12, 2014, 2016 and 2017, the views of local residents appeared mixed, with demands for greater state spending tempered by critiques of self-serving local politicians. Radio and press coverage questioned the work of the regional assembly, which was critiqued for being primarily concerned with its own survival. Meanwhile, Tarija's departmental elites denounced the whole autonomy project as 'unconstitutional'. As such, the Estatuto Autonómico Regional (Regional Autonomy Statute) was elaborated in a climate of uncertainty and contestation. Nevertheless, when the statute was put to a popular referendum in Gran Chaco Province on 20 November 2016, the 'yes' vote won with a resounding 72.4 per cent of votes (versus 27.6 per cent for 'no'), paving the way for the establishment of an executive branch of the regional government in 2017. Finally, this gave the Chaco's autonomy project a more legitimate and permanent status.

The above discussion demonstrates how the political upheavals that marked Morales' rise to power - centring on conflicts around the governance of the Chaco subsoil - provided new openings for chaqueño leaders to pursue their historic claim to regional autonomy. Beyond the contingencies of elite political manoeuvring, what perhaps stands out most in this account is that the MAS government sought to align itself not with Indigenous organisations and territorial projects in the Chaco - the architects and supposed beneficiaries of a plurinational state - but with provincial elites pursuing a regionalist project from which Indigenous peoples were until recently excluded. Even more surprising is that the discursive and legal framework for advancing regional autonomy was precisely that of plurinationalism.

\footnotetext{
${ }^{41}$ Chapter III of Law 4021, Article 76, states that, as stipulated in Article 280, paragraphs 1-3 of the Constitucion Politica del Estado (CPE): 'Gran Chaco Province of Tarija Department will opt for regional autonomy on 6 December 2009 via a referendum.'
} 


\section{Situating Regional Autonomy within a Plurinational State}

While the plurinational state was conceived of by Indigenous organisations in Bolivia as a means to transform the colonial structure of the state and accommodate their long-standing demands for self-governance of their ancestral territories, the concept of autonomy within the 2009 Constitution is not limited to Indigenous peoples, but encompasses a variety of forms of political decentralisation. For example, departments are defined as 'autonomous', while non-Indigenous peasants can be included in the AOIC category. As Raúl Prada observes, this is 'an institutional plural state', composed of 'multiple territorial ordinances', including 'Indigenous territorialities, local geographies, regional geographies and national cartographies. ${ }^{42}$ The 2009 Constitution defines regional autonomy as part of the territoriality of the plurinational state, noting that in exceptional cases, a region can be formed by a single province. ${ }^{43}$ Given that the political pact between the MAS and chaqueño elites was already in place in 2009, one wonders if this clause might have been written with Gran Chaco in mind.

The 2010 Autonomy and Decentralisation Framework Law provides a legal framework for the implementation of these different forms of autonomy. A region is defined here as:

A continuous territorial space composed of various municipalities or provinces which doesn't transcend the limits of the department, which has as its objective to optimise the planning and public management for integral development, and which constitutes a space of coordination and concurrence of public investment. Indigenous peasant territories, decided by their own norms and procedures, can be part of the region. ${ }^{44}$

Regional autonomy excludes legislative competencies and is limited to regional planning based on 'minimum goals of economic and social development [...] according to the conditions and potentialities of the region'. ${ }^{45}$ The Law places emphasis on the representation of Indigenous peoples and territorial entities within regional autonomy; not only can autonomous regions be demanded by Indigenous peoples, but Indigenous peoples are to be included in the regional planning process, including through representation in a regional economic and social council. ${ }^{46}$

While regional autonomy began as a project of non-Indigenous chaqueño elites from which Indigenous peoples were excluded, plurinationalism has thus provided the legal and constitutional framework for its implementation under the MAS government. Plurinationalism also represents a new discursive terrain for regional autonomy, enabling it to be reimagined as part of a wider process of building a plurinational state in Bolivia. Moreover, this plurinational framing has contributed towards opening spaces for Indigenous participation in the construction of regional

\footnotetext{
${ }^{42}$ Raúl Prada, 'Articulaciones de la complejidad', p. 10.

${ }^{43}$ Bolivia's 2009 Constitution, Article 280.

${ }^{44} 2010$ Ley Marco de Autonomías y Descentralización (Autonomy and Decentralisation Framework Law), Article 19.1, available at www.planificacion.gob.bo/uploads/marco-legal/Ley\%20N\%C2\%B0\% 20031\%20DE\%20AUTONOMIAS\%20Y\%20DESCENTRALIZACION.pdf, last access 29 Nov. 2021.

${ }^{45}$ Ibid., Article 23.

${ }^{46} \mathrm{Ibid}$., Article 24.1.
} 
autonomy in the Chaco. I now turn to examine the implications of these articulations for Chaco's Indigenous peoples and their decolonial projects.

\section{Navigating Pluri-Extractivism: Indigenous Peoples and Regional Autonomy From Exclusion to Incorporation}

Gran Chaco Province is home to three Indigenous peoples, the Guaraní, Weenhayek and Tapiete. Following a history of state-backed territorial dispossession, these Indigenous peoples began organising in the late 1980s around demands for territory. The 1996 Instituto Nacional de Reforma Agraria (National Institute for Agricultural Reform, INRA) Law led to the recognition of five territorial claims within the province: TCO Weenhayek, TCO Yaku-Igua (Guaraní), TCO Tapiete, TCO Itika Guasu (Guaraní) and TCO Karaparí, ${ }^{47}$ a Guaraní territorial claim recognised by the Bolivian state in 2008. With the exception of TCO Tapiete, all these territorial claims contain important gas reserves. Perhaps not coincidentally, all besides TCO Tapiete remain in a legally fragmented state following the TCO landtitling process, which remains incomplete (see Figure 3). That is, collective Indigenous land rights are not held over a contiguous area (the claimed TCO territory), but comprise a patchwork of isolated fragments of less-productive land that are interspersed with privately titled or unresolved property claims. These ambivalent land-titling outcomes are partly a result of inherent weaknesses in the INRA Law (which prioritises private property claims in TCOs provided they demonstrate productive land use), but also reflect the political dynamics of the titling process, which saw sustained opposition from non-Indigenous land claimants and the influence of hydrocarbon interests. ${ }^{48}$

This lack of territorial integrity and unfinished nature of the TCO titling process means that TCOs in Tarija are unable to gain formal Indigenous autonomy. The 2009 Constitution states that Indigenous autonomy is 'based on consolidated [i.e. titled] Indigenous territories and those in process, once consolidated' ${ }^{49}$ while the 2013 Ley de Unidades Territoriales (Law of Territorial Units) explicitly prohibits the recognition of Indigenous peasant autonomy in Indigenous territories that are not continuous. ${ }^{50}$ Indigenous peoples in Gran Chaco are also unable to achieve autonomy at a municipal level, as this requires winning a municipal referendum something that is impossible to achieve given their status as demographic minorities within their respective municipalities. This set of legal obstacles to achieving formal Indigenous autonomy provides important context for understanding why Indigenous peoples have sought participation in regional autonomy.

As noted above, early iterations of regional autonomy were based on a regional economic-development vision that overlooked the presence of Indigenous peoples entirely. This is unsurprising given that, during the early 1980s, many Indigenous

\footnotetext{
${ }^{47}$ The Guaraní spelling of TCO Karaparí distinguishes it from the name of the province of Caraparí in which the territorial claim is located. Both the territory and the province are named after the carapari cactus (spelled karapari in the Guaraní language) that grows abundantly in the region.

${ }^{48}$ Anthias, Limits to Decolonization.

${ }^{49}$ Bolivia's 2009 Constitution, Article 293.1.

${ }^{50}$ See Tockman and Cameron, 'Indigenous Autonomy and the Contradictions of Plurinationalism in Bolivia', p. 49.
} 


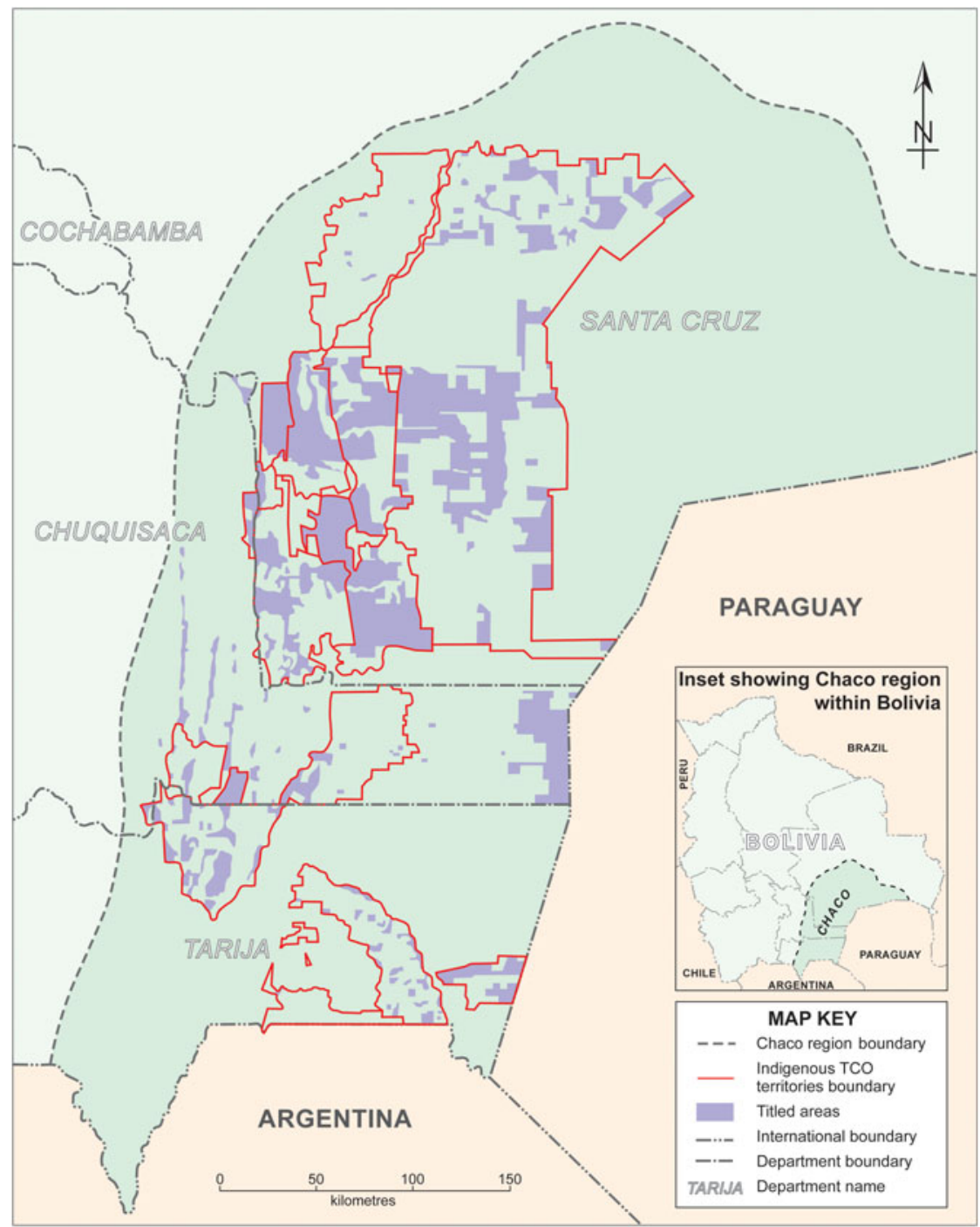

Figure 3. Map Showing Outcomes of TCO Land Titling in the Bolivian Chaco Source: Adapted with permission from Fundación TIERRA, Territorios Indígena Originario Campesinos en Bolivia: Entre la Loma Santa y la Pachamama (La Paz: Fundación TIERRA, 2011), p. 125. Previously printed in Anthias, Limits to Decolonization, p. 2.

families in the Chaco remained trapped in relations of semi-slavery on non-Indigenous haciendas, where they were subject to violent forms of discipline and lacked basic citizenship rights. As chaqueño politician Horacio Sánchez admitted, the protagonists of regional autonomy looked to local peasants, teachers and workers' federations for support:

Only on some occasions did they request - and this is painful - the help of Indigenous peoples. But almost never, as far as I remember, did they involve 
them, with an equitable and protagonist role, in the negotiations, in the demands. When they needed strength to block that bridge [...] they put some Indigenous people there to help - they gave them coca, alcohol, and that was it. But involve them - let's see, what ideas do you have? - no ... They didn't recognise them much because they didn't reclaim their rights. ${ }^{51}$

Nevertheless, following Indigenous mobilisation in the late 1980s, the Asamblea del Pueblo Guaraní (Guaraní People's Assembly, APG), established in 1987, led the way in challenging the 1989 Pacto de Quebracho and its proposal of a 'tenth department' in the Chaco, which encompassed and erased Guaraní ancestral territories. Instead, they proposed the establishment of an autonomous Guaraní Nation extending over the entire Chaco region of Bolivia - a proposal that struck fear into national as well as departmental and regional elites.

Given these precedents, it is not surprising that Chaco Indigenous people continued to express suspicion about Gran Chaco's regional autonomy project and its advance under the MAS. An event I attended on 'chaqueño peasant identity' in 2011 was illustrative. Organised by a local research non-governmental organisation (NGO) in Tarija City, the event gave voice to Indigenous peoples' deep distrust regarding the way in which regional identity was being used for political ends in ways that marginalised them. As one Guaraní leader commented: 'Why are they only talking about peasant identity and not about Indigenous peoples?" ${ }^{52}$ The Weenhayek participant observed: 'They always want to make us disappear' and noted that 'autonomy isn't new, it's what we did many years ago'. A female Guaraní leader expressed a similar sentiment, arguing: 'When they put forward the issue of autonomy, we already had it. Our ancestors weren't professionals but they had a lot of knowledge that stayed inside of us.' She claimed that the real objective of the event was to enlist Indigenous peoples' support for a non-Indigenous autonomy project, noting 'we continue to be betrayed, especially with the territorial issue in the Chaco'.

Despite these evident tensions, Indigenous peoples have ultimately gained significant representation within the Chaco's new regional institutions. Gran Chaco's Autonomy Statute stipulates that Indigenous peoples will have one assembly member for each of the three Indigenous peoples, who are to be elected 'according to their own usos y costumbres [norms and procedures]. ${ }^{53}$ This mirrors the broader structures of Bolivia's plurinational state; the 2009 Constitution and 2009 Ley Régimen Electoral Transitorio (Transitory Electoral Regime Law) created special Indigenous circumscriptions within the Chamber of Deputies, Plurinational Legislative Assembly and departmental legislative assemblies. Given the small size of Gran Chaco's regional assembly, the results of this special representation are striking: out of a total of nine asambleistas (assembly members), three are Indigenous, with the remaining six elected by popular vote. Indigenous representatives also argued that their presence in the regional assembly was a result of their

\footnotetext{
${ }^{51}$ Author interview with Horacio Sánchez, politician, Regional Assembly of Gran Chaco, Caraparí, 11 April 2017.

${ }^{52}$ All quotations in this paragraph are taken from Indigenous leaders speaking at the event I attended on 'chaqueño peasant identity', Tarija City, 2011.

${ }^{53}$ Autonomy Statute of Gran Chaco, Article 16.4.
} 
demands for representation, following their participation in mobilisations instigated by chaqueño leaders in 2001, 2004 and 2008 (see below).

Alongside this political representation, the Chaco's Regional Autonomy Statute, Regional Development Plan and Operating Regulations include various articles recognising Indigenous languages, symbols, practices and political concepts. For example, the regulations state:

The ethical principles on which service to the Chaco people is based are: YEYORA, OHUUMIN OCHOUMET [freedom], MBOREREKUA, LAIKYWEEJ $¡ I^{I I H I} i$ [solidarity and generosity], IYAMBAE, OWEEN OT ¡AMSEK [being without an owner, free of oneself], MBOROAIU, YOPARAREKO, INA ${ }_{j}$ AWHAWULHKIA [feeling of love, friendship, brotherhood, equality] YOMBOETE, YOPOEPI, OJWAAWALHIAJ IHII [respect for

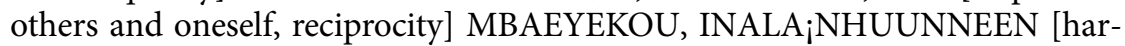
mony with oneself, equilibrium]. ${ }^{54}$

The preamble of the Autonomy Statute includes the following passage:

On this land, several racial groups coexisted, originating from the Pampa and its passage to the Amazon, fighting with courage to defend their habitat and their right to land and life, and finally fighting against European conquerors and republican colonists, giving rise to the historic mixing of the Chaco people and its strongest Indigenous peoples that transcended the history, such as the Guaraní, Weenhayek and Tapiete. ${ }^{55}$

This passage is reminiscent of the discourse of mestizaje that underpinned the foundation of Latin American republics, in which the mixing of Indigenous and Spanish blood - combined with an appropriation of Indigenous histories of anti-colonial resistance - served to give legitimacy to a national independence project led by criollo elites. Arguably, these examples amount to little more than an instrumental co-option of indigeneity to serve an elite-led project for capturing gas rents. It is unclear how Indigenous 'ethical principles' will translate into political practices and priorities. Nevertheless, the presence of three elected Indigenous representatives within the regional assembly represents a watershed in a region where Indigenous peoples were only in the 1990s recognised as rights-bearing citizens. The question arises: What, in practice, are Indigenous assembly members able to achieve? The following vignette provides some insights.

\section{Inside the Autonomous Regional Assembly}

The Asamblea Regional del Chaco is housed in a large concrete building (see Figure 4) on the outskirts of Caraparí, the smallest of the Gran Chaco's three urban centres and the site of important gas wells. When I first visited the assembly building in 2016, I was astounded by its sheer size. One of many 'white elephants'

\footnotetext{
${ }^{54}$ Asamblea Regional del Gran Chaco, 'Reglamento de Funcionamiento y Debate, Asamblea Regional del Gran Chaco' (2017), Article 4.1, p. 11. Emphasis in original document.

${ }^{55}$ Autonomy Statute of Gran Chaco, preamble.
} 
that have sprung up during the Chaco's gas bonanza, ${ }^{56}$ it appeared jarring against the backdrop of the lush green mountains of Aguaragüe, a national park co-managed by the Guaraní. ${ }^{57}$ The assembly's exterior is decorated with the Bolivian crest, the regional autonomy shield (see Figure 5), a wire illustration of a gas well, and a curious mural depicting hydrocarbon infrastructure and environmental destruction. Inside, wide corridors of mainly empty offices surround a giant concrete courtyard, containing what can only be described as a large paddling pool. As I toured the expanse of the building with Mauricio, the appointed advisor to the Guaraní assembly member, we contemplated possible uses for the pool; he suggested that the legislators could hold 'aquatic sessions' with towels, swimming trunks and piña coladas. Despite its opulent design, the building's deterioration over the past few years has become evident; the roof is now decayed and mouldy, and the concrete is starting to look aged. Already, the assembly is beginning to look like a relic from the gas boom.

During my first visit in 2016, I spent several days in the Indigenous peoples' bench of the regional assembly, chatting with Mauricio, the Guaraní asambleista Jorge, and other assembly employees. Outside and around the Indigenous offices, colourful posters show scenes from rural Indigenous life and declare the assembly's commitment to Indigenous cultures of the Chaco (see Figure 6). During this visit, Mauricio was optimistic about what Indigenous peoples could achieve based on their demographic weight within the assembly. Because the remaining six assembly members were split equally between the ruling MAS party and the right-wing opposition party Camino al Cambio (Path to Change, CC), Mauricio felt they were in a strong position to make demands in exchange for their political support. Given the assembly's limited powers, such demands were necessarily limited to inclusion within public spending plans and regional planning processes. Still, following a history of Indigenous exclusion from public institutions and minimal state investment in rural Indigenous communities, this was significant.

However, Guaraní asambleísta Jorge did not appear to share Mauricio’s optimism. Hailing from a rural community in Caraparí municipality, I have known Jorge since 2008, when he was an articulate leader at the forefront of a new territorial claim. Sitting behind his desk in his plush new office, he looked weary and dejected. He admitted that most of his work in the assembly was not directly related to the demands of Guaraní communities. Indeed, many of his activities related to ensuring the continuing existence of the regional assembly, which remained in a precarious state pending the popular referendum approving the Regional Autonomy Statute later that year. When I asked about the Guaranís current priorities within the assembly, he mentioned a series of construction projects, many of which were paralysed due to lack of funds. However, he reflected that the Guaraní would not really benefit from these roads anyway, given that they were mainly subsistence producers. Meanwhile, he noted that Guaraní communities in Caraparí municipality had still received nothing from the departmental

\footnotetext{
${ }^{56}$ 'White elephants' ('elefantes blancos') is used locally to refer to the many giant concrete edifices built during the gas boom, which provide kickbacks for local politicians and their cronies in the construction industry.

${ }^{57}$ The principle aquifer for the entire Chaco region, Aguaragüe has seen intensifying hydrocarbon development since 2009 .
} 


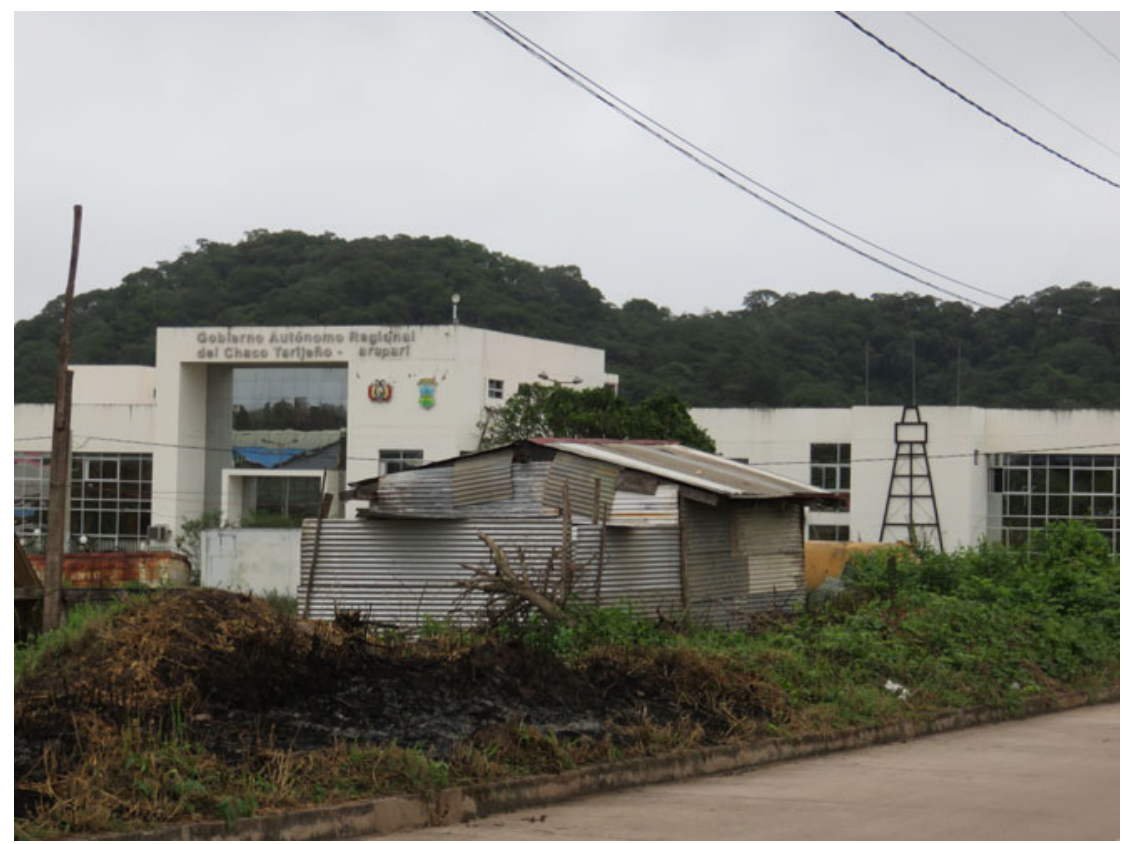

Figure 4. The Autonomous Regional Assembly of the Chaco Tarijeño Source: Photo by author.

cash transfer programme PROSOL (Programa Solidario) - a result of the fact they have still not obtained legal personhood as Indigenous communities (discussed below).

When I returned to Caraparí in 2017, the regional assembly had acquired a somewhat more permanent status, following a regional referendum on 20 November 2016, in which the Regional Autonomy Statute received a 'yes' vote of 72.4 per cent. This assured the regional assembly's future and set in motion the establishment of the executive branch of the regional government. I met Mauricio in the central plaza of Caraparí and we walked together towards the assembly. He paused at a measured distance from the building to update me on the internal politics of the Indigenous bench. He explained that, while the three Indigenous legislators initially had a political pact with the ruling MAS party, this had broken down. The Guaraní representative Jorge had remained aligned with the MAS, the Weenhayek representative had made a pact with the right-wing party, while the Tapiete representative had been removed from his position owing to an administrative technicality - namely, his failure to formally 'resign' from his post before being re-elected by his people. ${ }^{58}$ As such, while the Indigenous representatives made up three out of nine legislators, they had remained divided by rival party interests, whose promises often remained unfulfilled. As Mauricio concluded:

\footnotetext{
${ }^{58}$ The representative eventually returned to his position after winning a constitutional sentence, in which he argued that these procedures undermined Indigenous peoples' right to elect representatives according to their own 'norms and procedures'.
} 


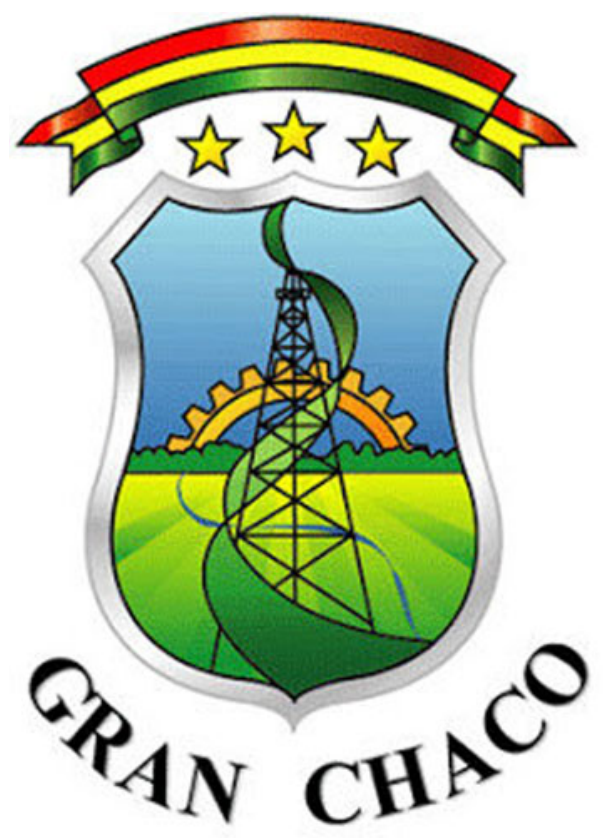

Figure 5. The Official Shield of the Autonomous Regional Government of the Chaco Tarijeño Note: This shield is reproduced on the regional assembly's documents and building.

Source: Agencia Chaqueña de Información, available at http://achi-yba.blogspot.com/2012/08/los-simbolos-regionales-delgran-chaco.html, last access 2 Dec. 2021.

'The Indigenous peoples have always been an instrument to benefit interest groups and their political priorities. And unfortunately, the three [Indigenous representatives] have not been able to act in a coordinated way to demand the fulfilment of promises. And part of these promises is that effective and significant resources arrive to the three [Indigenous] peoples. ${ }^{59}$

The susceptibility of Indigenous representatives to division and co-option by rival party interests should not be taken as evidence of the colonial stereotype of the easily bribable Indian. The Guaraní, in particular, have a long tradition of forging temporary alliances with multiple factions as a means of evading control by karai (non-Indigenous) political institutions - something that has been called 'Guaraní diplomacy'. ${ }^{60}$ These divisions must also be read in the context of the MAS government's efforts to consolidate its political hegemony, in ways that have narrowed the room for manoeuvre for Indigenous activists in Bolivia. Increasingly, political opponents have found themselves silenced, imprisoned, exiled or excluded from access to public institutions and funds. ${ }^{61}$ This exacerbates the dilemmas faced by Indigenous representatives in the Chaco.

\footnotetext{
${ }^{59}$ Author interview with Mauricio, advisor to the Guaraní assembly member, Caraparí, 2017.

${ }^{60}$ Francisco Pifarré, Los Guaraní-Chiriguano: Historia de un pueblo (La Paz: CIPCA, 1989), p. 294, cited in Postero, The Indigenous State, p. 177.

${ }^{61}$ Nancy Postero and Nicole Fabricant, 'Indigenous Sovereignty and the New Developmentalism in Plurinational Bolivia', Anthropological Theory, 19: 1 (2019), pp. 95-119.
} 


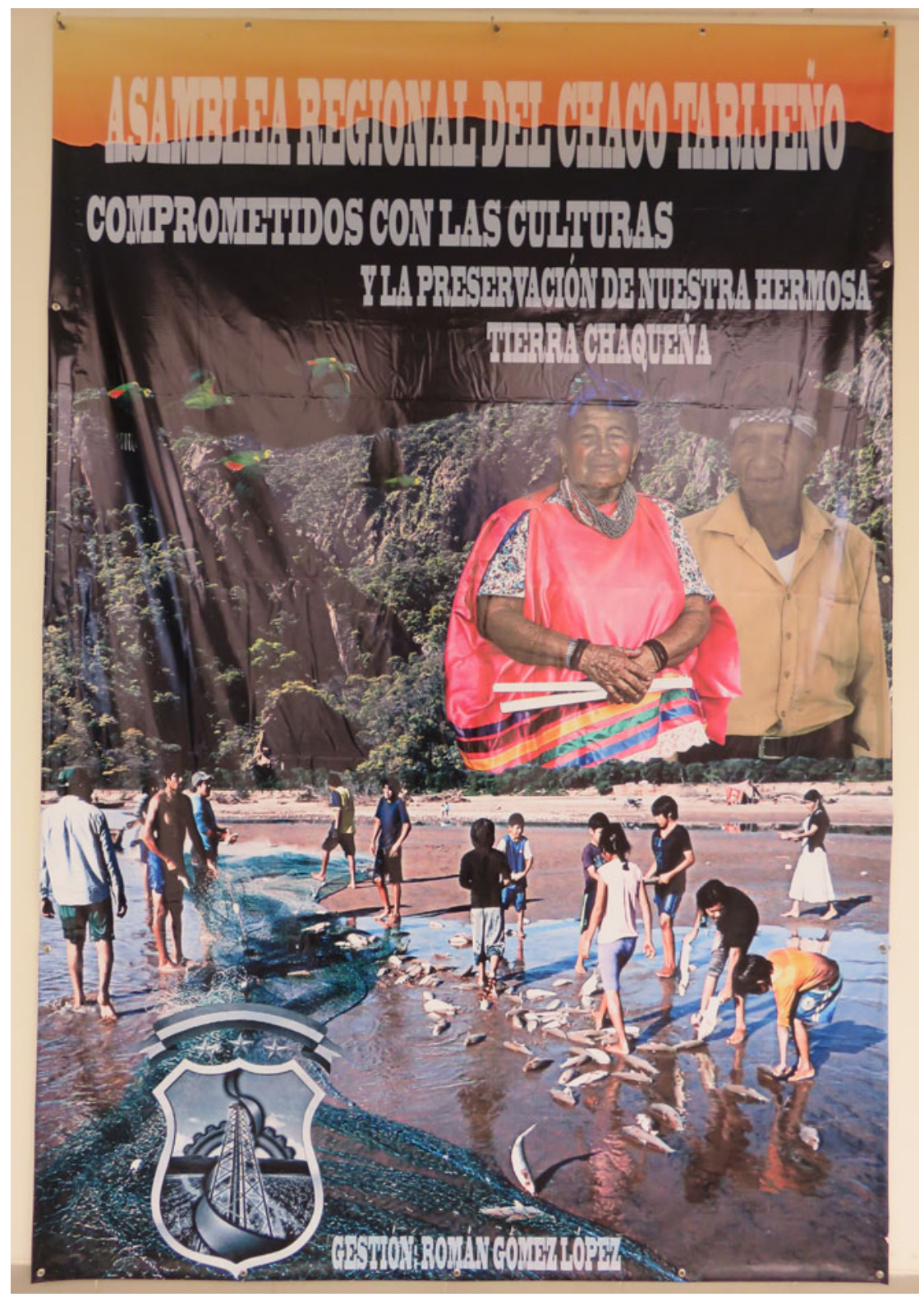

Figure 6. Poster Hanging by Indigenous Peoples' Bench of Regional Assembly Note: This poster states that the assembly is 'committed to the cultures and the preservation of our beautiful Chaco land'.

Source: Photo by author.

Jorge, the Guaraní representative in the assembly, reminded me that the Guaraní have always maintained a non-aligned position vis-à-vis political parties - a position I have heard repeated many times in Guaraní assemblies. He described how 
the need to make political alliances with the two main political parties compromised the value Guaraní place on an independent 'autonomous' stance. ${ }^{62}$ It had also caused division between the three Indigenous legislators, he explained, with offers from political parties undermining Indigenous people's sense of having their own political vision. Jorge admitted feeling unable to achieve much in his role, aside from securing a few small projects for Guaraní communities in exchange for his political support for one of the main parties. He also complained that Guaraní communities did not put forward their demands or take advantage of his position - an indication of the distancing from Indigenous communities that often follows absorption of Indigenous leaders into the state. Despite these challenges, however, he expressed optimism. Once the executive branch of the Chaco regional government was established, Indigenous legislators would be able to approve all fiscal policies of the provincial government, he noted, providing further opportunities to direct state resources towards rural Indigenous communities.

Notwithstanding this possibility, Jorge admitted that his position did not allow him to address the most pressing problem for Guaraní communities in Caraparí municipality: access and rights to land, which was beyond the assembly's competencies. While the question of Indigenous land claims remains unresolved throughout the Bolivian Chaco, these communities' situation is particularly acute. Excluded from earlier processes of Indigenous mobilisation in the 1980s and 1990, these Guaraní communities only recently formed their own Indigenous organisation, the APG Karaparí, presenting a TCO claim to the Bolivian state in 2006. In 2008, an investigation by the International Labour Organization (ILO) confirmed the continuing existence of forced-labour practices in the municipality, which are known locally as empatronamiento (a form of debt peonage).

Under the 2009 Constitution and revised INRA agrarian reform law of 2008, the discovery of such practices is grounds for state expropriation of private land to award to Indigenous claimants. However, this has not occurred in TCO Karaparí. To date, the MAS government has only recognised one of 22 communities included in the territorial claim (see Figure 7), subjecting the remainder to a process of individual land titling that has privileged non-Indigenous land claimants and 'invisibilised' Guaraní communities, many of which have found themselves trapped within the boundaries of private properties. While sustained opposition of local peasant organisations aligned with the MAS has been a major obstacle, many Guaraní believe the state's unwillingness to recognise their territorial claim is due to the existence of important gas reserves in the territory. Meanwhile, the state's refusal to grant these communities legal personhood means that hydrocarbon development continues to unfold without prior consultation. ${ }^{63}$

The land situation also affects communities' ability to access state development projects. Jorge gave the example of Cañon Ancho, where the Guaraní community live inside the property of their patrón, who presented himself as the leader of the community and succeeded in getting funding for cattle-ranching projects from the municipality and provincial government. While these projects are of no benefit to

\footnotetext{
${ }^{62}$ This complaint is frequently made by Indigenous bureaucrats in Tarija, including representatives within the departmental legislative assembly (author interviews, Tarija, 2017).

${ }^{63}$ I observed this first-hand during a visit to affected communities in 2019.
} 


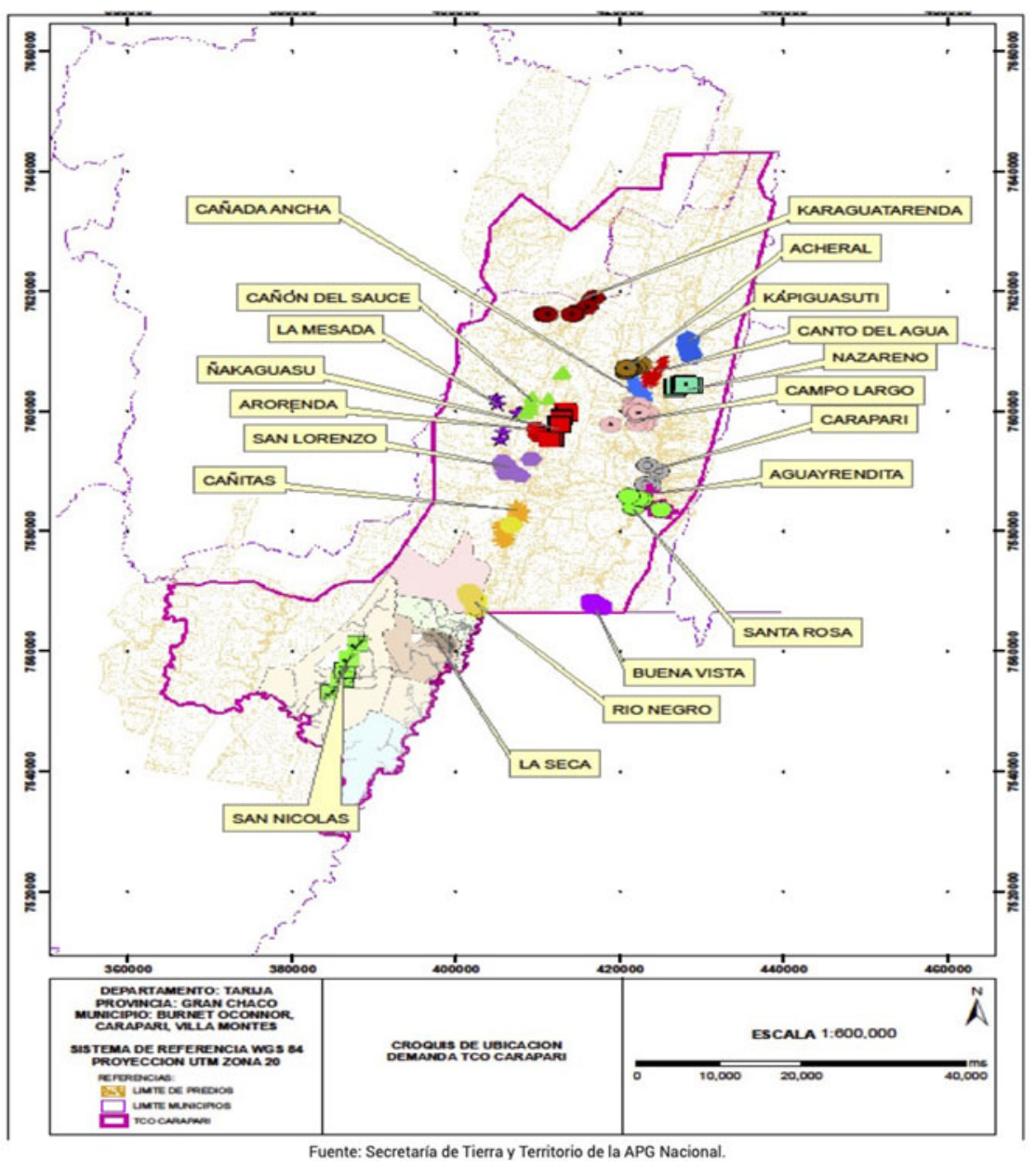

Figure 7. Guaraní Communities Included in the Karaparí TCO Claim

Note: At the date of publication, only Kápiguasuti had been granted legal personhood as an Indigenous community. Source: Secretariat of Land and Territory of the APG, reprinted in Defensoría del Pueblo, 'Estado de situación del ejercicio del derecho a la tierra y al territorio por parte de las familias guaraníes en el Municipio de Caraparí' (La Paz: Defensoría del Pueblo, 2014), p. 24.

Guaraní families, Jorge described how people remained silent owing to the patrón's continuing power in the community. While there is not space here for a detailed discussion of these broader challenges of decolonising territory, it is notable that Indigenous representation within the Autonomous Regional Assembly does little to resolve the ongoing forms of territorial and environmental dispossession faced by Indigenous communities in the Chaco.

Indigenous representatives were quick to acknowledge these limitations. Yet, they also described how occupying the state formed part of long-term Indigenous agendas for decolonisation and resource justice. A Guaraní-Spanish translator within the regional assembly critiqued the rigid laws and statutes of the assembly, but also 
argued that the presence of Indigenous peoples in the assembly was 'opening up a path' for future generations, which was 'not going to open on its own' ${ }^{64}$ A departmental Indigenous legislator argued that participation in state institutions was a means of addressing long-standing Indigenous grievances regarding the unequal distribution of economic benefits and environmental costs of extraction, and of advancing Indigenous development priorities - from budgets for bilingual teachers to changing the school calendar to accommodate the fishing season. He explained:

We're hopeful about regional autonomy because [...] it's better that our authorities are from the region; an authority that is self-governing, manages its own resources, is an authority that knows the needs that we have ... As Indigenous peoples, we could take advantage of this space to generate and work on projects that benefit our people, not depend anymore on people from here [Tarija City]. ${ }^{65}$

As this demonstrates, despite facing ongoing forms of racialised exclusion within the Chaco, some Indigenous leaders share the critique of departmental centralism that underpinned demands for regional autonomy. This leader also saw Indigenous participation in the Chaco's regional government as a just recompense for the sacrifices Indigenous peoples had made in social mobilisations in defence of regional autonomy. As he put it:

Regional autonomy has been an achievement, it's been a struggle that has not only been by the people of the city. Guaraní, Tapiete, Weenhayek have also been part of this struggle [...] the famous 45 per cent that they've achieved for the Chaco, we also fought for that conquest, and the criollos - we say criollo for the people of the city - don't recognise us. That is, they don't recognise the sacrifice that the Indigenous person also made to achieve something for their benefit [...] it's like the Chaco War, you know that [the dominant narrative of] the Chaco War doesn't mention a single Indigenous person, but our ancestors tell us another history, which the karai are reluctant to recognise. Worse still if we want to [gain credit for] this [regional] autonomy process. Why? Because this will affect [...] it will affect their pocket [their money]. The resources they manage they don't want the Indigenous person to manage, you see. That's the total reality that exists today. ${ }^{66}$

As this passage reveals, Indigenous participation in regional autonomy gains meaning in the context of a long struggle for postcolonial recognition. Throughout history, Chaco Indigenous peoples' erasure from regional and national historiography has legitimised their exclusion from political and economic power. Indigenous demands for a seat at the table of regional autonomy can be read as an act of resistance to these ongoing acts of erasure. As the final sentences of the

\footnotetext{
${ }^{64}$ Author interview with Guaraní-Spanish translator, Asamblea Regional del Gran Chaco, April 2017.

${ }^{65}$ Author interview with anonymous departmental Indigenous legislator, Departmental Assembly, Tarija City, 9 May 2017.

${ }^{66}$ Ibid.
} 
quotation imply, such recognition is also viewed as connected to ongoing struggles over the distribution of gas rents. Concretely, Indigenous representatives have been fighting for a fixed 15 per cent share of the regional assembly's annual income to be allocated directly to Indigenous organisations - a proposal that would represent a significant shift in regional power relations and the territoriality of regional governance, albeit without departing from an extractivist development model.

The above testimonies make clear that, for all the ambivalences of regional autonomy, Indigenous representatives are not simply political instruments of elite interests. Rather, by occupying spaces in the pluri-extractivist state, they engage in acts of strategic manoeuvring and resistance against a long history of racialised rule. ${ }^{67}$ As another Indigenous departmental legislator argued:

I think [participation in the regional assembly] is worth a lot, it's our grain of sand that we've put there, because in this way Indigenous peoples are being taken into account, that we're also capable of occupying a space, a political space - we feel capable, because before they said 'you, no, you don't know, so stay there', but now the same people are realising that Indigenous peoples are capable. ${ }^{68}$

\section{Defending Gran Chaco's 45 Per Cent?}

What these 'grains of sand' will achieve over the coming years and decades remains to be seen. The steady decline of Gran Chaco's gas reserves, combined with shifting geographies of hydrocarbon extraction, mean that the future of regional autonomy is far from certain. During my 2017 fieldwork, the beginning of seismic testing in Tariquía National Park (located in Tarija Department but outside of Gran Chaco Province) was already generating heated debates about whether Gran Chaco's 45 per cent share of departmental royalties could be justified. Politicians in neighbouring O'Connor Province were leading calls for a more just distribution among provinces, while rural communities had mobilised in a march on the regional capital to demand a new ' 8 per cent law' allocating a fixed share of departmental hydrocarbon royalties to non-Chaco municipalities.

On 11 May 2017, I attended a meeting in the Municipal Council of Yacuiba, whose purpose was to devise strategies to defend the Chaco's 45 per cent in the face of these various challenges. The invitation letter sent to Indigenous representatives described the event as 'a meeting of COORDINATION, ${ }^{69}$ which will touch on themes of great importance for the Chaco's population, such as: Law $3038-45$ Per Cent of Hydrocarbon Royalties; treatment of the Fiscal Pact and 8 Per Cent Transference Law; various points'. Various local politicians gave speeches, arguing that the 45 per cent was part of Gran Chaco's 'patrimony' as an entidad territorial autónoma (autonomous territorial entity) under the 2009 Constitution, and that it

\footnotetext{
${ }^{67}$ Sarah Radcliffe and Andrew Webb, 'Subaltern Bureaucrats and Postcolonial Rule: Indigenous Professional Registers of Engagement with the Chilean State', Comparative Studies in Society and History, 57: 1 (2015), pp. 248-73.

${ }^{68}$ Author interview with anonymous departmental Indigenous legislator, Departmental Assembly, Tarija City, 9 May 2017.

${ }^{69}$ Emphasis in original letter.
} 
was recognised in law and in the Regional Autonomy Statute, and was therefore 'untouchable'. One man proposed the creation of ' 20 padlocks' through different articles of law to ensure the 45 per cent could not be challenged.

Tellingly, Indigenous representatives provided more critical interventions. Most compelling was the speech by the Weenhayek departmental representative. He began by greeting the audience in Weenhayek, reminding everyone that, under the 2009 Constitution, everyone had the right to express themselves in their own language. He said it was an honour to be invited and at a moment when 'unity calls us' in Gran Chaco. While Indigenous peoples wanted to be part of this, however, he reminded participants that 'this unity shouldn't be only for the issue of resources' ${ }^{70}$ There were also natural disasters - recent drought and declining fish stocks had decimated Indigenous communities - which also called for regional unity. He noted that during the past two years, departmental Indigenous assembly members had not received a single visit, suggestion or paper from the Chaco's regional authorities. Despite this, he and other Indigenous representatives had been called to defend Gran Chaco's 45 per cent. He emphasised: 'We [Indigenous peoples] have suffered for a very long time amidst the boom of Tarija Department, of Gran Chaco', inviting the audience to visit Indigenous communities, which 'had not received benefits that have an impact in our TCO, our territory'. He noted that Indigenous peoples 'have been shouting and complaining for years' about not receiving their share of benefits, even though the Constitution recognises that attention should be given to the demands of communities directly affected by hydrocarbon development. Indigenous peoples were aware of this, he said, because 'the part that suffers is not the city - the environmental impacts are suffered by us, inside our territory'.

As this makes clear, Indigenous support for regional autonomy is not unconditional, nor is it uncritical. While there are clear limits on what Indigenous representatives are able to achieve within an extractivist state, Indigenous representatives use their presence within these political spaces to voice prescient critiques of broader structures of colonial power, environmental dispossession and resource injustice. It is in transforming these broader geographies of territory and power - not only in pluralising political institutions - that the challenge of decolonisation lies.

It is also worth noting that Chaco Indigenous peoples have abandoned their hopes for alternative, Indigenous-led visions of autonomy and plurinationalism. Indeed, the possibilities of pursuing the two established routes to Indigenous autonomy - Indigenous peasant territories and Indigenous municipalities - remain a frequent topic of conversation among Indigenous organisations. Indigenous peoples are also engaged in creative strategies for consolidating their territorial claims, such as the physical occupation of state lands (which provides a pragmatic alternative to the ongoing struggle for rights to privately claimed properties within TCO land claims). As such, regional autonomy is just one of multiple arenas in which Indigenous peoples in the Chaco are seeking to strategically navigate competing notions of territory and sovereignty in defence of their own agendas of territory and self-determination. ${ }^{71}$

\footnotetext{
${ }^{70}$ All quotations in this paragraph are taken from participants speaking at the meeting I attended at the Municipal Council of Yacuiba, 11 May 2017.

${ }^{71}$ See Postero and Fabricant, 'Indigenous Sovereignty'.
} 


\section{Conclusion}

While plurinationalism and extractivism have previously been seen as competing projects within Bolivia's 'process of change', this article has revealed how they are becoming articulated in local processes of state formation in the Chaco. The successful campaign for regional autonomy in Gran Chaco highlights how local actors rework the relationship between extraction, territory and citizenship 'from the ground up' to produce new forms of territoriality. Bolivia's plurinational state provides a new context for such articulations, which risk displacing and subordinating Indigenous peoples' own visions of autonomy and plurinationalism. A focus on these local dynamics of state formation enriches debates on extractivism, moving beyond a focus on state-led dispossession and place-based resistance to reveal how Indigenous decolonial projects are also compelled to navigate competing subnational claims for territory and resource sovereignty.

Of course, this is not only a story about local state formation. It is also an account of the consolidation of central state power by the MAS government, which has used subnational demands for autonomy and fiscal decentralisation to weaken political opposition in the lowlands. The success of regional autonomy in Gran Chaco reflects the bargaining power of local elites in the context of broader disputes over political authority, nature and nation. ${ }^{72}$ This sheds important light on the limits to decolonisation within an extractivist development model. Despite overseeing the most radical constitution in Bolivia's history, the MAS government's reliance on subsoil resources located in Indigenous territories has led to the formation of historically familiar alliances of sovereignty with non-Indigenous landowning elites in the lowlands, which have been prioritised over Indigenous demands for territory and autonomy.

Despite these ambivalences, this article has revealed how Indigenous peoples have demanded representation within Gran Chaco's regional government and are seeking to use this as a means to advance their own political agendas - such as inclusion within regional planning processes, the allocation of state funds to Indigenous development priorities, and the breaking down of historic structures of racialised rule. I have argued that strategic navigation of elite-dominated political spaces is a necessary part of Indigenous decolonial politics in Tarija, and does not signal an abandonment of broader Indigenous agendas of territory and selfdetermination. Still, the accounts of Indigenous representatives highlight the limits of these political spaces, where colonial power structures, bureaucratic obstacles and clientelistic party politics limit Indigenous representatives' ability to centre Indigenous development priorities. Of course, these dynamics are nothing new; clientelism, corporatism, corruption and racism are long-standing features of state institutions in Tarija Department. In that sense, pluri-extractivism may be a vehicle for continuity and 'gatopardismo' as much as it is a new configuration of power. ${ }^{73}$ The ongoing dispossession and abandonment suffered by rural Indigenous

\footnotetext{
${ }^{72}$ See Arellano-Yanguas and Mejia Acosta, 'Extractive Industries, Revenue Allocation and Local Politics'.

${ }^{73 ،}$ 'Gatopardismo' refers to 'the policy of changing everything so that everything remains the same'; see Silvia Rivera Cusicanqui, 'Ch'ixinakax utxiwa: A Reflection on the Practices and Discourses of Decolonization', South Atlantic Quarterly, 111: 1 (2012), p. 101.
} 
communities in the Chaco sheds further critical light on the limits of Indigenous representation within an extractivist state.

In the context of shifting hydrocarbon geographies and declining gas fields, the future of Gran Chaco's regional autonomy is uncertain. Competing subnational claims to autonomy and gas rents raise questions about what alternative articulations of pluri-extractivism may emerge over the coming years in Tarija Department and beyond. How Indigenous peoples will navigate these shifting territorial and resource politics, and to what extent they will succeed in recentring and consolidating their own visions of Indigenous autonomy within a plurinational state, remains to be seen.

Acknowledgements. This research benefitted from funding from the Independent Research Fund Denmark Project: LEAKS: Resource Enclaves and Unintended Flows in Latin America, and from the European Research Council (ERC) Grant: State Formation through the Local Production of Property and Citizenship (Ares (2015)2785650 - ERC-2014-AdG - 662770-Local State). I am extremely grateful to the three anonymous reviewers, to JLAS editors and to Sarah A. Radcliffe and Lauren Martin for their helpful comments on earlier drafts of this article.

\section{Spanish abstract}

El 20 de noviembre de 2016, residentes de la provincia del Gran Chaco en el sudeste de Bolivia votaron por referéndum popular para aprobar una estatua que establecía al Gran Chaco como la primera región autónoma de Bolivia. Este artículo examina la construcción de la autonomía regional en el Chaco como un ejemplo de cómo identidades, territorio y poder político están siendo re-mapeados en la intersección de un modelo de desarrollo extractivista y visiones encontradas de un estado plurinacional. Se expone cómo las demandas de larga data de las élites del Chaco por un repartimiento fijo de las ganancias del gas ganaron apoyo de parte del gobierno del Movimiento al Socialismo bajo la forma de plurinacionalización como una forma de consolidar su propio poder en el Chaco. También considera las implicaciones de la autonomía regional para los pueblos indígenas del Chaco que han adquirido una representación significativa al interior de la nueva asamblea autónoma regional, al tiempo que sus propias visiones de autonomía regional son hechas a un lado por una agenda del desarrollo extractivista.

Spanish keywords: Bolivia; extractivismo; plurinacionalismo; autonomía; formación estatal; pueblos indígenas

\section{Portuguese abstract}

Em 20 de novembro de 2016, os residentes da província do Gran Chaco, no sudeste da Bolívia, votaram por referendo popular para aprovar um estatuto que estabeleceu o Gran Chaco como a primeira região autônoma da Bolívia. Este artigo examina a construção da autonomia regional no Chaco como um exemplo de como identidades, território e poder político estão sendo remapeados na intersecção de um modelo de desenvolvimento extrativista e visões concorrentes de um estado plurinacional. Eu mapeio como as demandas de longa data das elites do Chaco por uma parcela fixa dos royalties do gás ganharam o apoio do governo do Movimento pelo Socialismo sob o pretexto de plurinacionalismo como meio de consolidar seu próprio poder no Chaco. Também considero as implicações da autonomia regional para os povos indígenas do Chaco, que alcançaram 
uma representação significativa na nova assembleia regional autônoma, ao mesmo tempo em que veem suas próprias ideias de autonomia territorial marginalizadas por uma agenda de desenvolvimento extrativista.

Portuguese keywords: Bolívia; extrativismo; plurinacionalismo; autonomia; formação de estado; povos indígenas

Cite this article: Anthias P (2022). The Pluri-Extractivist State: Regional Autonomy and the Limits of Indigenous Representation in Bolivia's Gran Chaco Province. Journal of Latin American Studies 54, 125-154. https://doi.org/10.1017/S0022216X21000997 